\title{
Earthworms promote the accumulation of rhizodeposit carbon to soil macroaggregate in a Mollisol of northeast China, primarily in long-term no-till soil
}

\author{
Xinyu Zhu ${ }^{1}$, Yunchuan $\mathrm{Hu}^{1}$, Zhiguo $\mathrm{Li}^{1}$, Donghui $\mathrm{Wu}^{2,3,4,}$, \\ 1 School of Surveying and Planning, Shangqiu Normal University, Shangqiu 476000, China \\ 2 Key Laboratory of Wetland Ecology and Environment, Northeast Institute of Geography and Agroecology, Chinese Academy of Sciences, \\ Changchun 130102, China \\ 3 Jilin Provincial Key Laboratory of Animal Resource Conservation and Utilization, Northeast Normal University, Changchun 130117, China \\ 4 Key Laboratory of Vegetation Ecology, Ministry of Education, Northeast Normal University, Changchun 130024, China
}

\section{H I G H L I G H T S}

- Earthworms increased soil macroaggregate (>2 $\mathrm{mm}$ and $0.25-2 \mathrm{~mm}$ ) formation.

- Maize roots and earthworms interact to produce soil macroaggregate.

- Earthworms were effective in transferring rhizodeposit carbon into macroaggregate, especially in soil derived from a long-term no-till system.

- Rhizodeposits were protected during soil aggregation.

\section{ARTICLE INFO}

Article history:

Received April 28, 2020

Revised August 11, 2020

Accepted August 25, 2020

Keywords:

Earthworms

Root-derived carbon

Soil aggregation

Isotope labeling

Rhizodeposotion

Tillage

\section{GRAPHICAL ABSTRACT}

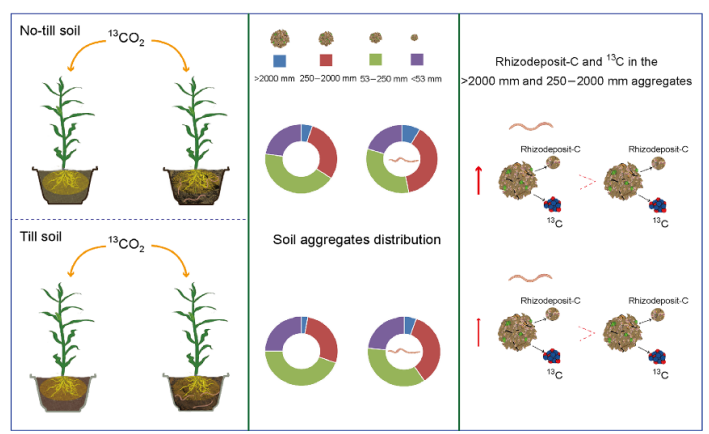

\section{A B S TR A C T}

As soil ecosystem engineers, earthworms are the main promoters of soil aggregation, a process that drives the production of ecosystem services by soils. A crucial factor in the ecosystem service of carbon sequestration is rhizodeposit carbon, which is the main energy source of soil food webs. The effects of earthworms on the distribution of rhizodeposit-carbon in soil aggregates remain unclear. Here, we conducted a ${ }^{13} \mathrm{CO}_{2}$ labeling experiment to determine the effects of earthworms on maize rhizodeposit carbon in soil aggregates after 14 years (2002-2016), in both conventional tillage (CT) and conservation tillage (no tillage, NT) soils. Four treatments were established in total: NTE (no tillage soil with earthworms), CTE (conventional tillage soil with earthworms), NTC (control, no tillage soil without earthworms), and CTC (control, conventional tillage soil without earthworms). Earthworms significantly enhanced the abundance of soil macroaggregates (>2000 $\mu \mathrm{m}$ and 250 $2000 \mu \mathrm{m}$ ) on day 30 compared with day 2 (after labeling), especially in the NT soils. On day 30, in the presence of earthworms, the amounts of rhizodeposit carbon in the $>2000 \mu \mathrm{m}$ and $250-2000 \mu \mathrm{m}$ soil aggregates in the NT soils were significantly higher than in those in the CT soils $(P<0.05)$, and higher $\delta{ }^{13} \mathrm{C}$ signatures in the same size aggregates were observed in the NT soils than in the CT soils $(P<0.05)$. These findings indicated that compared with the CT soils, with the involvement of earthworm activity, the NT soils promoted more rhizodeposit carbon transformation to the soil macroaggregates. Our results clearly indicate that soil macroaggregates formed in different tillage soils in the presence of 2 different engineers (earthworms and roots) significantly differ from those formed in the presence of only one organism (roots) in the long term.

(c) Higher Education Press 2020

\footnotetext{
* Corresponding author

E-mail address: wudonghui@iga.ac.cn (D. Wu)
} 


\section{Introduction}

Soil aggregates are the main component of soil structure, and their turnover is related to the activities of organisms that live within the soil (Six et al., 2004). Soil microaggregates bind more firmly than soil macroaggregates, thus providing more stable long-term storage for soil organic carbon (SOC) (Six et al., 2002). However, soil macroaggregates are key in providing sites for soil microaggregate formation (Six et al., 2000). The renewal of soil aggregates is a key process in the soil system which is increased by the activities of soil fauna (Six et al., 2000; Gong et al., 2019).

As ecosystem engineers, earthworms affect soil structure and nutrient cycling via their burrowing, feeding, and casting activities, which influence soil organisms and SOC decomposition (Brown et al., 2004; Fonte et al., 2012). The process of SOC stabilization is highly dependent on the formation and stability of soil aggregates, which are affected by the activities of earthworm (Bossuyt et al., 2005; Six and Paustian, 2014). Lubbers et al. (2017) reported that earthworms can increase the incorporation of residual carbon into soil aggregates in the short term, and aid in the decomposition of SOC in the long term. Soil and plant residues that are ingested by earthworms are mixed in their guts (Zangerlé et al., 2011), and the residual carbon is then rapidly protected by the microaggregates and macroaggregates in the soil (Bossuyt et al., 2005; Fonte et al., 2012). Although fresh leaf litter can contribute to the formation of soil aggregates through leachable organic compounds as aggregate binders, roots and rhizodeposits could be the main source of fresh organic matter that promotes the formation of soil macroaggregates (Fahey et al., 2011). An earlier investigation demonstrated that roots have a relatively larger effect on soil carbon pools, and the greater retention of rootderived carbon has been attributed to physical protection by soil aggregates (Wander and Yang, 2000). It has been suggested that increasing rhizodeposit carbon distribution could have positive or negative effects on soil carbon sequestration (Rogers et al., 1994; Wilson et al., 2009; Cheng et al., 2012). Additionally, Boone et al. (1998) found that live roots and rhizodeposition are key factors in regulating carbon sequestration rates. Most crops in agricultural soils supply much more leaf litter than root litter and, therefore, the soil aggregates have more leaf-derived carbon than rootderived carbon (Denef and Six, 2006). On the other hand, another investigation showed that root litter lasted longer in soil aggregates formed from crops (Kong and Six, 2010). Furthermore, recent studies have demonstrated that earthworms consume large amounts of root-derived carbon and incorporate it into soil aggregates (Gilbert et al., 2014; Sánchez-de León et al., 2014). Also, the labile substances released by living roots significantly increase SOC mineralization by up to $27 \%$ to $245 \%$ (Zhu et al., 2014). The relationships between these labile substances and earthworms are very close, and earthworms can change the fate of rhizodeposit carbon by increasing its accessibility to soil microbes (Huang et al., 2015). However, the effects of earthworms on the relatively more accessible carbon that is released into the rhizosphere and on the formation of soil aggregates have not been fully clarified. Therefore, a better understanding of the effects of earthworms on the transfer of rhizodeposit carbon to soil aggregates is needed.

Conservation tillage regimes, including no tillage (NT), have received attention because these practices can reduce soil erosion and increase the carbon sequestration of agricultural surface soils by increasing the stability of soil aggregates. The number of carbon-rich soil macroaggregates increases after implementation of NT, as the disturbance of soil decreases and soil fauna changes (Six et al., 2004). However, the soil organic matter turnover rate increases, the amount of soil aggregates decreases, and organic matter decomposition increases under intensive tillage (Six et al., 2000). The role of earthworms is particularly interesting in the long-term NT regime, because this practice can increase the number of earthworms and soil aggregate size (Bai et al., 2018). The number of soil surface-feeding earthworms that mix residues into the soil can be increased by increasing the utilization rate of surface soil residues and reducing the physical disturbance of NT soils, and this would alter the soil nutrient availability and soil structure. Furthermore, plant productivity (van Groenigen et al., 2014) and the proportion of photosynthesized carbon that is incorporated into the soil by earthworm activity is increased by earthworms (Nieminen et al., 2015; Huang et al., 2015). However, under different tillage regimes, the proportional contribution of earthworms to the relatively more accessible rhizospheric carbon, which is a vital factor in soil carbon sequestration, remains unclear. The development of rhizosphere management strategies for carbon sequestration and cropland soil fertility can be facilitated by an improved understanding.

In this investigation, a ${ }^{13} \mathrm{CO}_{2}$ labeling experiment was carried out to analyze the effects of earthworms on the mass of soil aggregates and the distribution of rhizodeposit carbon in soil aggregates under different tillage regimes. We hypothesized that 1) the presence of earthworms in either soil type would increase soil macroaggregate formation; and 2) compared to the CT soils with earthworms, increased biomass inputs related to earthworm activity in the NT soils would increase the contribution of rhizosphere carbon (rootderived carbon) to soil aggregate carbon storage.

\section{Materials and methods}

\subsection{Site description and microcosm setup}

The investigation site was established at the Experimental Station of the Northeast Institute of Geography and Agroecology $\left(44^{\circ} 12^{\prime} \mathrm{N}, 125^{\circ} 33^{\prime} \mathrm{E}\right)$, Chinese Academy of Sciences, Dehui County, Jilin Province, China. Mean annual temperature is $4.4^{\circ} \mathrm{C}$; the coldest month of the year is January $\left(-19.5^{\circ} \mathrm{C}\right)$, and the warmest month is July $\left(24.5^{\circ} \mathrm{C}\right)$. Mean annual precipitation is $520 \mathrm{~mm}$, and more than $70 \%$ of the annual precipitation occurs from June to August. The soil type 
Table 1 Soil physical and chemical properties under different tillage treatments before the experiment.

\begin{tabular}{lll}
\hline Tillage & $\mathrm{NT}$ & $\mathrm{CT}$ \\
\hline $\mathrm{SOC}\left(\mathrm{g} \mathrm{kg}^{-1}\right)$ & $21.77 \pm 0.31$ & $15.95 \pm 0.65$ \\
$\mathrm{TN}\left(\mathrm{g} \mathrm{kg}^{-1}\right)$ & $1.38 \pm 0.06$ & $1.11 \pm 0.03$ \\
$\mathrm{NO}^{3-}-\mathrm{N}\left(\mathrm{mg} \mathrm{kg}^{-1}\right)$ & $36.24 \pm 1.97$ & $25.72 \pm 0.55$ \\
$\mathrm{NH}^{4+}-\mathrm{N}\left(\mathrm{mg} \mathrm{kg}^{-1}\right)$ & $16.38 \pm 2.37$ & $17.01 \pm 0.57$ \\
$\mathrm{BD}\left(\mathrm{g} \mathrm{cm}^{-3}\right)$ & $1.33 \pm 0.11$ & $1.30 \pm 0.21$ \\
$\mathrm{pH}$ & $5.89 \pm 0.21$ & $5.97 \pm 0.19$ \\
$\mathrm{C} / \mathrm{N}$ & $15.82 \pm 0.43$ & $14.32 \pm 0.68$ \\
${ }^{13} \mathrm{C}(\%)$ & $-18.44 \pm 0.29$ & $-19.55 \pm 0.27$ \\
\hline
\end{tabular}

is Mollisols soil (USDA soil taxonomy) with clay-loam texture (36\% clay, $24 \%$ silt, and $40 \%$ sand) (Liang et al., 2007). The relevant soil properties prior to the experiment are presented in Table 1. In the NT system, the soil was not disturbed, except when the crops were planted with a KINZE-3000 NT planter. In the CT system, autumn moldboard plowing $(18-20 \mathrm{~cm})$ was followed by secondary seedbed preparation by disking (7.5$10 \mathrm{~cm}$ ) in the spring. After harvesting, the maize straw in the NT system was cut into small pieces (approximately $15 \mathrm{~cm}$ ), leaving stubble 15-20 cm long, and then returned to the soil surface. In the CT system, all maize residue on the soil surface was plowed below the soil surface during autumn tillage.

Two types of soil were used in this investigation - one from an NT system and the other from a CT system. Both systems had been planted with a maize monoculture and were cultivated for 14 years (2002-2016). The entire setup was presented in detail by Zhu et al. (2019). In short, a randomized block design was used in this investigation, with a total of 4 treatments (NTE (no tillage soil with earthworms), CTE (conventional tillage soil with earthworms), NTC (control, no tillage soil without earthworms), and CTC (control, conventional tillage soil without earthworms)), and each treatment had 5 replicates. In early September of $2016,800 \mathrm{~g}$ of treated soil was placed in each nylon bag (mesh size $\leqslant 0.3 \mathrm{~mm}, 30$ $\mathrm{cm}$ long $\times 20 \mathrm{~cm}$ wide; nylon bag to prevent earthworms from escaping), and distilled water was added $\left(150 \mathrm{~mL} / \mathrm{kg}^{-1}\right)$ to reach $70 \%$ water-filled pore space (WFPS). Finally, each nylon bag was placed in a plastic pot (approximately $11.5 \mathrm{~cm}$ in diameter by $14 \mathrm{~cm}$ in height).

\subsection{Collection and inoculation of earthworms}

Epigeic earthworms (Esienia nordenskiodi pallida Malevič, 1956) were hand-sorted in the field at the same location as the soils in late August 2016. Because the earthworm distribution was aggregated in the field, a slight population density of earthworms (4 ind. Pot $^{-1}$, approximately $385 \mathrm{~m}^{-2}$ ) was used to make it easier to detect the effects of earthworms on soil carbon dynamics (Boag et al., 1994; Zhang et al., 2013; Zhu et al., 2016). The earthworms were placed on wet filter paper for $48 \mathrm{~h}$ so they could void their guts prior to being placed in the pots when the maize seedlings were transplanted. Furthermore, $3 \mathrm{~g}$ of sterilized plant litter (a mixture of maize and weeds) previously collected from the same field site was added to the surface of each pot to provide sufficient food for the earthworms and to imitate the field environment.

\subsection{Labeling chamber and ${ }^{13} \mathrm{CO}_{2}$ labeling}

A labeling chamber (1.8 m long $\times 1.2 \mathrm{~m}$ wide $\times 1.4 \mathrm{~m}$ high) was built in July of 2016 for the injection and monitoring of $\mathrm{CO}_{2}$. It was made of acrylic glass (roof, $2 \mathrm{~mm}$ thick; walls, 5 $\mathrm{mm}$ thick) and contained two probes: a $\mathrm{CO}_{2}$ concentration probe (Taishi TES 1370, China) and a high-precision temperature and relative humidity meter (Hengxin AZ8726, China). The modified $\mathrm{CO}_{2}$ concentration detector probe was connected via a sensor to a ${ }^{13} \mathrm{C}$-labeled and unlabeled $\mathrm{CO}_{2}$ gas cylinder. A small air conditioner was placed in the labeling chamber to maintain the temperature at approximately $25^{\circ} \mathrm{C}$. The plants (maize) in the chamber were watered every 3 or 4 days using a drip irrigation system.

Labeling started (in late September of 2016 - 15 days after the earthworm inoculation) after the earthworms had gradually adapted to their new environment. The specific methods of ${ }^{13} \mathrm{CO}_{2}$ labeling we followed are described in Zhu et al. (2019). Briefly, ${ }^{13} \mathrm{CO}_{2}$ (99 at. $\%{ }^{13} \mathrm{C}$, Sigma Aldrich Corporation, USA) was delivered into the chamber for 4 consecutive days between 11:30 am and 1:00 pm (Kaštovská and Šsantrůčková, 2007). On cloudy days, a $\mathrm{CO}_{2}$ concentration of approximately $370-400$ ppm was delivered for 30 minutes, and on sunny days, a higher $\mathrm{CO}_{2}$ concentration (approximately $500 \mathrm{ppm}$ ) was delivered for $1 \mathrm{~h}$. Approximately $10 \mathrm{~L}$ of ${ }^{13} \mathrm{CO}_{2}$ had been used at the end of the 4-day labeling period.

\subsection{Sampling and analyses}

Destructive sampling was conducted on days 2 and 30 after labeling. The main reason for the short duration was that we aimed to avoid any possible interference and wanted to focus on the effects of earthworms on the readily available rhizodeposit carbon (Gilbert et al., 2014). To obtain the soil samples, the whole maize root system was first dug out and gently shaken to remove large pieces of soil without root (bulk soil), and then all soil attached to the root surface was removed by shaking. Finally, the soil samples were carefully placed in bags by hand. This fraction is referred to thereafter as rhizospheric soil (Zhang et al., 2011). The soil samples were air-dried to analyze the $\delta^{13} \mathrm{C}$ signatures in the soil aggregates. The maize was separated into roots and stems + leaves, which were cleaned with tap water and then rinsed with deionized water. All maize materials were oven-dried at $55^{\circ} \mathrm{C}$ and then used to analyze the $\delta^{13} \mathrm{C}$ signatures and carbon content. The earthworms were counted by handsorting; then, all earthworms were rinsed with deionized water and euthanized by placing them in a freezer at $-20^{\circ} \mathrm{C}$ for approximately 5 minutes. Next, the guts of the earthworms were dissected, and the contents were washed with deionized water and collected. The tissue and gut contents were then 
freeze-dried to analyze the $\delta^{13} \mathrm{C}$ signatures and carbon content.

Soil aggregate fractionation by wet-sieving was carried out following the methods adapted from Elliott (1986) and Six et al. (2000), and 4 aggregates were obtained: 1) large soil macroaggregates (>2000 $\mu \mathrm{m}), 2$ ) small soil macroaggregates $(250-2000 \mu \mathrm{m}), 3)$ soil microaggregates $(53-250 \mu \mathrm{m})$ and 4$)$ silt and clay $(<53 \mu \mathrm{m})$. Briefly, $80 \mathrm{~g}$ of air-dried soil was immersed in deionized water on a $2 \mathrm{~mm}$ sieve. After 5 minutes, the sieve was shaken up and down 50 times in 2 minutes. The soil remaining on the sieve was then rinsed into a pre-weighed aluminum pan, while the soil passing through the $2 \mathrm{~mm}$ sieve was transferred to a $250 \mu \mathrm{m}$ sieve. The process was repeated with the $250 \mu \mathrm{m}$ and $53 \mu \mathrm{m}$ sieves until each of the 4 fractions was weighed in their respective preweighed pans. Each of these fractions was rinsed into preweighed aluminum pans and oven-dried at $60^{\circ} \mathrm{C}$, and the $\delta^{13} \mathrm{C}$ signatures were then measured as described below.

Prior to the isotopic and carbon content analyses, all dried materials were ground using a ball mill and sieved through $a<0.15 \mathrm{~mm}$ mesh. Then, the $\delta^{13} \mathrm{C}$ signatures in the earthworm tissues, soil aggregates, and maize were determined following standard procedures using stable isotope ratio mass spectrometry (MAT 253, Thermo Fisher, USA) after the samples were concentrated, centrifuged, and dried. The results were calculated as follows: $\delta^{13} \mathrm{C}(\%)=$ $\left[\left({ }^{13} \mathrm{R}_{\text {sample }} /{ }^{13} \mathrm{R}_{\text {standard }}\right)-1\right] \times 1000$, where ${ }^{13} \mathrm{R}={ }^{13} \mathrm{C} /{ }^{12} \mathrm{C}$; Pee Dee Belenite (PDB) was used as the standard for ${ }^{13} \mathrm{C}$. Jones et al. (2009) reported that plant roots are generally assumed to be responsible for a large fraction of the rhizodeposition process and that the $\delta^{13} \mathrm{C}$ signature of roots reflects the $\delta^{13} \mathrm{C}$ value of both root respiration and rhizodeposit-related respiration. In our investigation, the $\delta^{13} \mathrm{C}$ value was used as an indicator of the $\delta^{13} \mathrm{C}$ signature in rhizodeposits, including both the ${ }^{13} \mathrm{C}$-labeled and non-labeled newly photosynthetic carbon. Therefore, according to Huang et al. (2015), rhizodeposit carbon in the soil aggregates and earthworms was calculated as follows:

$$
\begin{gathered}
\mathrm{C}_{\text {soil }}=\left(\delta^{13} \mathrm{C}_{\mathrm{SOC}-\mathrm{t} 0}-\delta^{13} \mathrm{C}_{\mathrm{SOC}-\mathrm{t} 1}\right) /\left(\delta^{13} \mathrm{C}_{\mathrm{SOC}-\mathrm{t} 0}-\delta^{13} \mathrm{C}_{\text {root }}\right) \\
\mathrm{C}_{\text {aggregates }}=\left(\delta^{13} \mathrm{C}_{\text {aggregates }-\mathrm{t} 0}-\delta^{13} \mathrm{C}_{\text {aggregates }-\mathrm{t} 1}\right) \\
/\left(\delta^{13} \mathrm{C}_{\text {aggregates }-\mathrm{t} 0}-\delta^{13} \mathrm{C}_{\text {root }}\right) \\
f_{\text {aggregates }}=\mathrm{C}_{\mathrm{TOC}-\text { aggregates }} \times \mathrm{C}_{\text {aggregates }} \\
\mathrm{C}_{\text {gut content }}=\left(\delta^{13} \mathrm{C}_{\mathrm{SOC}-\mathrm{t} 0}-\delta^{13} \mathrm{C}_{\text {gut content }}\right) /\left(\delta^{13} \mathrm{C}_{\mathrm{SOC}-\mathrm{t} 0}-\delta^{13} \mathrm{C}_{\text {root }}\right)
\end{gathered}
$$

Where, $\mathrm{C}_{\text {soil }}$ is the fraction of rhizodeposit carbon in the soil, $\delta^{13} \mathrm{C}_{\text {root }}$ is the $\delta^{13} \mathrm{C}$ in the plant roots, and $\delta^{13} \mathrm{C}_{\text {Soc-to }}$ and $\delta^{13} \mathrm{C}_{\text {SOC-t1 }}$ are $\delta^{13} \mathrm{C}$ of the soil prior to and after labeling, respectively. $\mathrm{C}_{\text {aggregates }}$ is the fraction of rhizodeposit carbon in the large macroaggregates $(>2000 \mu \mathrm{m})$, small macroaggregates $(250-2000 \mu \mathrm{m})$, soil microaggregates $(53-250 \mu \mathrm{m})$, and silt and clay $(<53 \mu \mathrm{m})$ respectively. $\delta^{13} \mathrm{C}$ aggregates-to and $\delta^{13} \mathrm{C}_{\text {aggregates-t1 }}$ are $\delta^{13} \mathrm{C}$ of the given soil aggregates prior to and after labeling, respectively. $f_{\text {aggregates }}$ is the amount of rhizodeposit carbon in the soil aggregates, and $\mathrm{C}_{\mathrm{TOC}}$-aggregates is the total organic carbon in aggregates. $\mathrm{C}_{\text {gut content }}$ is the fraction of the rhizodeposit carbon in the earthworm gut contents, and $\delta^{13} \mathrm{C}_{\text {gut content }}$ is the $\delta^{13} \mathrm{C}$ of the gut contents after labeling.

\subsection{Statistical analysis}

The influence of soils and earthworms on soil aggregates and $\delta^{13} \mathrm{C}$ signatures, as well as rhizodeposit carbon in the soil aggregate fractions, was examined using analysis of variance (ANOVA). The earthworms, soils (NT and CT), and earthworm $\times$ soil interaction were considered the main effects. Where the homogeneity of variance was satisfied, a least-significant difference (LSD) test was used to compare the means; otherwise, the data were log10 or square root-transformed. All statistical analyses were conducted with SPSS 16.0 (SPSS Inc., Chicago, IL, USA), and statistical significance was evaluated at $P<0.05$.

\section{Results}

\subsection{Mass of soil aggregates}

Soil aggregates $>2000 \mu \mathrm{m}$ were more abundant in the NTE treatment than in the CTE treatment both on days $2(P<0.01)$ and $30(P<0.05)$ (Fig. $1 A$ and $B)$. On day 30, soil aggregates that were 250-2000 $\mu \mathrm{m}$ in the treatments with earthworms (NTE and CTE) were more abundant than those without earthworms (NTC and CTC), and there were significant differences between the NTE and NTC treatments $(F=$ 23.888, $P=0.035$ ) (Fig. 1B). The presence of earthworms significantly decreased the content of soil aggregates measuring 53-250 $\mu \mathrm{m}(F=7.310, P=0.011)$. Compared to the result on day 2 , the content of soil aggregates $>2000 \mu \mathrm{m}$ in the NTE treatment significantly increased on day $30(F=$ 9.834, $P=0.035)$. On day 30 , the abundances of soil aggregates 250-2000 $\mu \mathrm{m}$ in the NTE $(F=13.932, P=0.020)$ and CTE $(F=9.570, P=0.036)$ treatments were significantly higher than those on day 2. The contents of soil aggregates 53-250 $\mu \mathrm{m}$ in the NTE $(F=32.392, P=0.005)$ and CTE $(F=$ 14.336, $P=0.019$ ) treatments on day 30 significantly decreased compared to those on day 2 .

Compared with the results on day 2 , the absolute mass of soil aggregates $>2000 \mu \mathrm{m}(P=0.035)$ and $250-2000 \mu \mathrm{m}(P=$ $0.020)$ in the NTE treatments and the absolute mass of soil aggregates $>2000 \mu \mathrm{m}(P=0.036)$ in the CTE treatment significantly increased on day 30 (Fig. $2 A$ and B). On day 30 , earthworms significantly increased the absolute mass of soil aggregates $>2000 \mu \mathrm{m}(P=0.048)$ and 250-2000 $\mu \mathrm{m}(P=$ 0.008 ) in NT soils (Fig. 2B). However, in the CT soils, the presence of earthworms only increased the absolute mass of soil aggregates $>2000 \mu \mathrm{m}(P=0.041)$. In the treatments with earthworms, tillage significantly affected the masses of $>2000$ $\mu \mathrm{m}$ soil aggregates $(P=0.024)$ (Fig. 2B). 


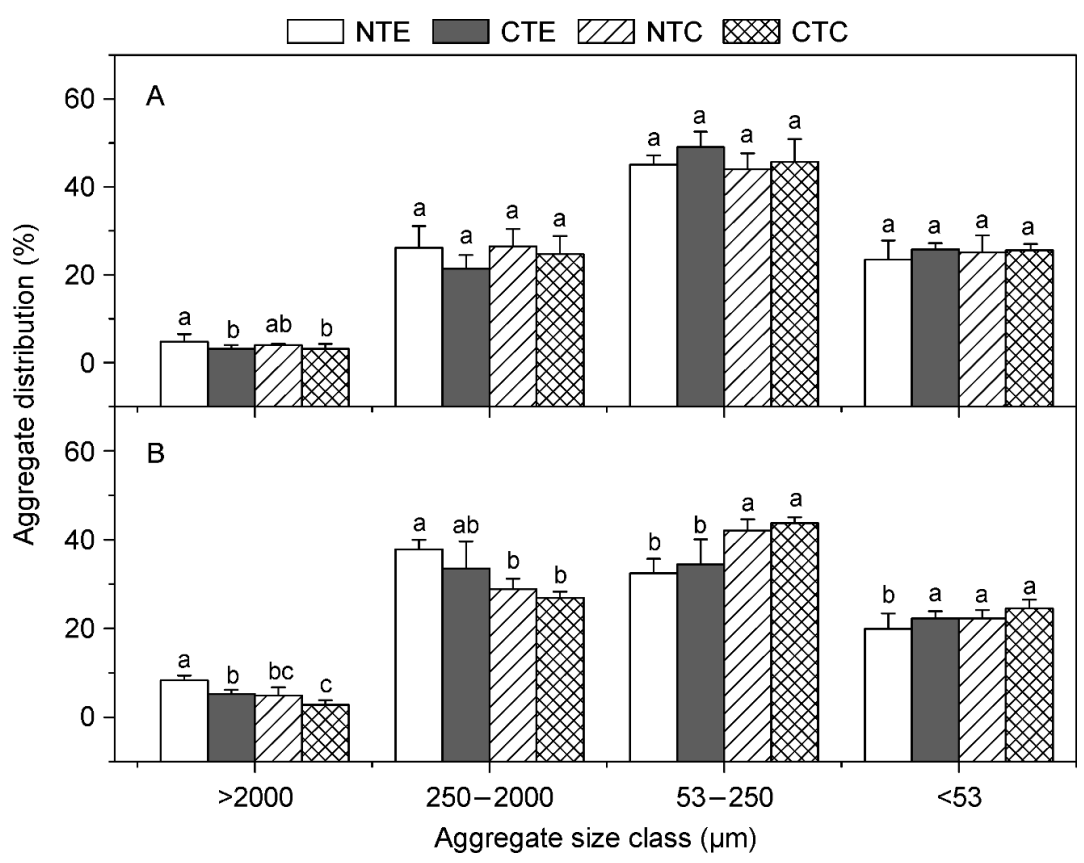

Fig. 1 Mass distribution of soil aggregate under different tillage regimes on day $2(A)$ and on day 30 (B). Different letters indicate significant differences between treatments.

$3.2 \delta^{13} \mathrm{C}$ signatures and rhizodeposit carbon retained in the soil aggregates

Compared with the results from day 2 , the $\delta^{13} \mathrm{C}$ signatures in each soil aggregate increased to different degrees on day 30 , but there were significant differences in the treatments with earthworms (Fig. 3A and B). On day 30, the earthworms had significant effects on the $\delta^{13} \mathrm{C}$ signatures of the soil macroaggregate fractions $(>2000 \mu \mathrm{m}, F=59.666, P<0.001 ; 250$ $2000 \mu \mathrm{m}, F=64.946, P<0.001$ ) (Fig. 3B, Table 2). Compared to the CT soils, the NT soils with earthworms had significant effects on the $\delta^{13} \mathrm{C}$ signatures of soil aggregates $>2000 \mu \mathrm{m}$

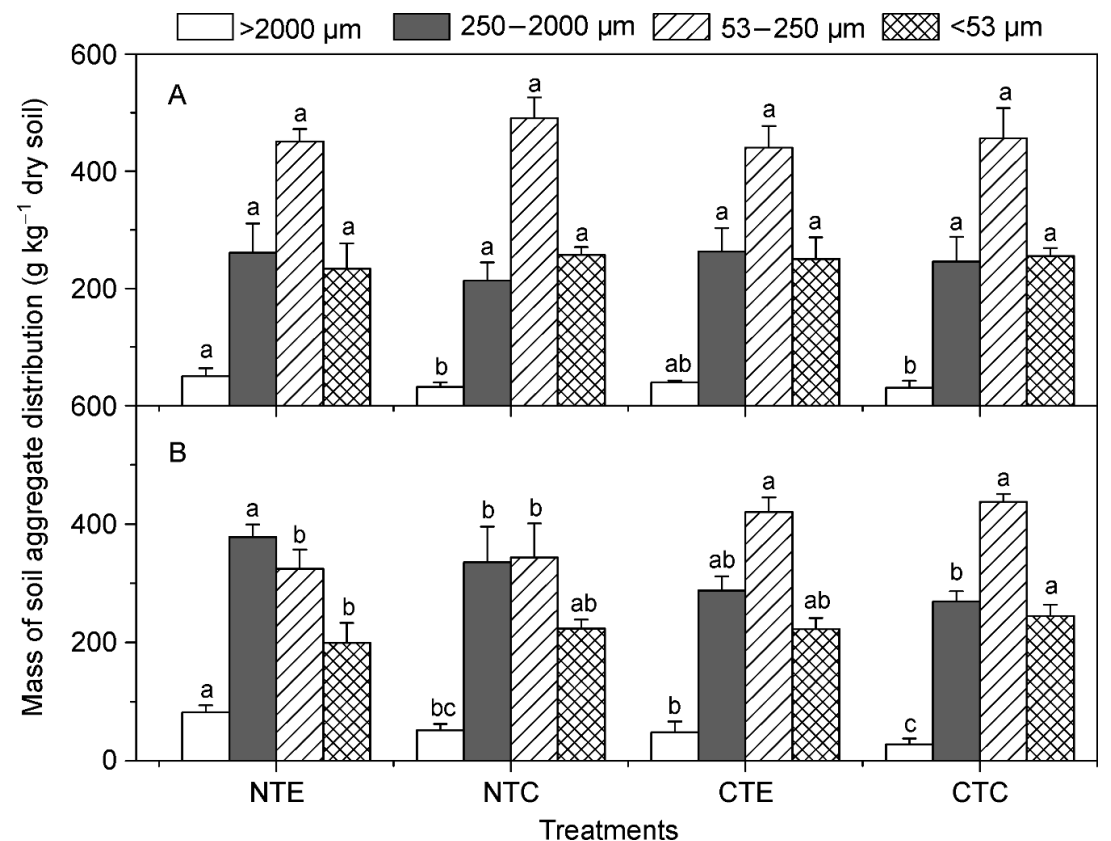

Fig. 2 Absolute mass of soil aggregates on day 2(A) and on day 30 (B). Different letters indicate significant differences between treatments. 


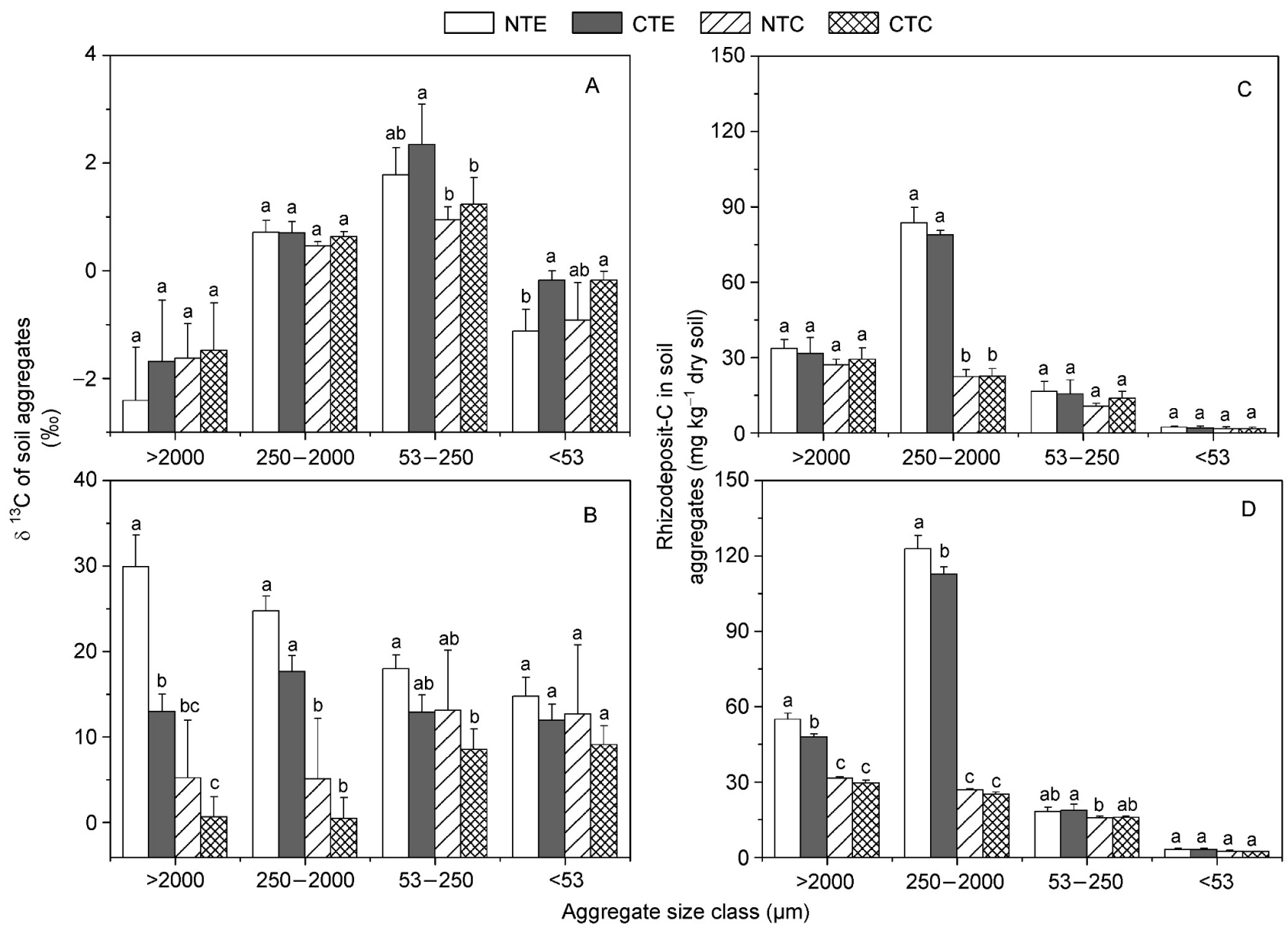

Fig. $3 \delta^{13} \mathrm{C}$ signatures (A, day 2; $B$, day 30 ) and rhizodeposit carbon ( $C$, day2; $D$, day 30 ) in the soil aggregates. Different letters indicate significant differences between treatments.

$(F=48.312, P=0.002)$. The interaction between earthworms and the different tillage soils $(E \times S)$ only had a significant effect on the $\delta^{13} \mathrm{C}$ signatures of soil aggregates $>2000 \mu \mathrm{m}(F=$ $6.603, P=0.033)$.

On day 2, there were no significant differences in rhizodeposit carbon among other soil aggregates except for the $>2000 \mu \mathrm{m}$ soil aggregates (Fig. 3C). More rhizodeposit carbon was retained in the $>2000 \mu \mathrm{m}$ and $250-2000 \mu \mathrm{m}$ soil aggregates in the treatments containing earthworms than in those without earthworms (day 30, $P<0.001$ ) (Fig. 3D). NT soils with earthworms retained more rhizodeposit carbon in the $>2000 \mu \mathrm{m}(F=21.009, P=0.010)$ and $250-2000 \mu \mathrm{m}(F=$ 8.551, $P=0.043$ ) soil aggregates than in the CT soils (Fig. 3D). Moreover, the interaction between earthworms and the different tillage soils had significant effects on the rhizodeposit carbon in the soil macroaggregate fractions (>2000 $\mu \mathrm{m}, F=9.118, P=0.017 ; 250-2000 \mu \mathrm{m}, F=5.627, P=$ 0.045) (Table 2). Compared to the results of day 2, the rhizodeposit carbon in the $>2000 \mu \mathrm{m}$ (NT soils, $P=0.001$; CT soils, $P=0.013$ ) and 250-2000 $\mu \mathrm{m}$ (NT soils, $P=0.001$; CT soils, $P<0$ ) soil aggregates on day 30 significantly increased both in NT and CT soils in the presence of earthworms.

\section{Discussion}

\subsection{Soil aggregate distribution}

The earthworms significantly macroaggregated the soils. In just over one month, compared to the results of day 2, large soil macroaggregates (>2000 $\mu \mathrm{m})$ and small soil macroaggregates (250-2000 $\mu \mathrm{m})$ increased significantly on day 30 in the treatments with earthworms (Fig. 1). These results confirm the capacity of these organisms to transform large amounts of soil in relatively short periods of time. This observation, which has been made for earthworms in several previous studies (Zangerlé et al., 2011; Arai et al., 2013), had not been made for the coexistence of earthworms with roots, especially in soils with different tillage regimes. This finding indicates that ecosystem engineers can macroaggregate soil very rapidly when the conditions are favorable.

Our results showed that the NT soil facilitated more soil macroaggregates with the activities of earthworms compared to the CT soils (Fig. 1B). Studies have demonstrated that many factors can affect soil aggregate formation, such as soil fauna (especially earthworms), tillage regimes, and soil 
Table $2 F$-and $P$-values of ANOVA (analysis of variance) on the effects of earthworms (with and without) and different tillage soils (NT and CT) on the $\delta^{13} \mathrm{C}$ signatures and rhizodeposit-carbon across soil aggregates.

\begin{tabular}{|c|c|c|c|c|c|c|c|}
\hline \multirow[t]{2}{*}{ Index } & \multirow{2}{*}{$\begin{array}{l}\text { Soil } \\
\text { aggregates }\end{array}$} & \multicolumn{2}{|c|}{ Earthworms (E) } & \multicolumn{2}{|c|}{ Soils (S) } & \multicolumn{2}{|c|}{ Earthworms $\times$ soils $(E \times S)$} \\
\hline & & $F$ & $P$ & $F$ & $P$ & $F$ & $P$ \\
\hline \multirow[t]{4}{*}{$\delta^{13} \mathrm{C}$ signatures } & $>2000$ & 59.666 & 0.000 & 20.095 & 0.002 & 6.603 & 0.033 \\
\hline & $250-2000$ & 64.946 & 0.000 & 6.593 & 0.033 & 0.300 & 0.599 \\
\hline & $53-250$ & 4.126 & 0.077 & 4.558 & 0.065 & 0.011 & 0.921 \\
\hline & $<53$ & 0.934 & 0.362 & 1.591 & 0.243 & 0.023 & 0.883 \\
\hline \multirow[t]{4}{*}{ Rhizodeposit-carbon } & $>2000$ & 592.978 & 0.000 & 27.698 & 0.001 & 9.118 & 0.017 \\
\hline & $250-2000$ & 2662.057 & 0.000 & 11.468 & 0.010 & 5.627 & 0.045 \\
\hline & $53-250$ & 8.823 & 0.018 & 0.112 & 0.746 & 0.001 & 0.982 \\
\hline & $<53$ & 4.912 & 0.058 & 0.033 & 0.860 & 0.147 & 0.711 \\
\hline
\end{tabular}

Significant effects are highlighted in bold $(P<0.05)$.

microorganisms (Pinheiro et al., 2004; Pulleman et al., 2005; Arai et al., 2013). The growth and turnover of roots and their exudates, factors that drove belowground productivity in this investigation area (Zhang et al., 2013; Zhang et al., 2018), are probably important soil aggregate binding agents. As binding agents, soil microbial biomass plays a crucial role in the formation and stabilization of soil aggregates (Six et al., 2004). Reduced tillage and increased crop residues could improve the physical, chemical, and nutrient habitat characteristics of soil microbes, thereby promoting microbial growth (Rillig, 2004). Furthermore, under conservation tillage, earthworm activities become prominent and their abundance was almost always higher than that under CT (Capowiez et al., 2009; Ayuke et al., 2011; Briones and Schmidt, 2017). In our previous investigation, the survival rates of earthworms were higher in NT soil than in CT soil (Zhu et al., 2019) and it is presumed that earthworm guts can provide binding materials for soil macroaggregate formation (Judas, 1992). Studies showed that earthworms increased soil microbial density and mixed crop residues and soil, which increased the resource supply of soil microbes, thereby favoring microbial density (Groffman et al., 2015; Gong et al., 2019).

Our results also indicated that the beneficial influence of maize on soil aggregation could depend on the presence of earthworms and/or the carbon input related to maize roots (Zhu et al., 2019). Some studies have suggested that the stability of earthworm casts and soil macroaggregates is correlated with soil carbon content (Jouquet et al., 2008; Kong and Six, 2010; Fonte et al., 2012), as organic matter forms the basis of stable bonding agents that hold aggregates (including casts) together (Guggenberger et al., 1996). Therefore, the beneficial effects of plant roots on the observed soil aggregates could be related to earthworm activity, the interaction between earthworms and soil microbes, and the aggregation of roots on soil aggregates (Angers and Caron, 1998). The reduction in soil microaggregates might be because new macroaggregates were formed because of the rearrangement of these microaggregate fractions. In a microcosm experiment, Bossuyt et al. (2005) found that more soil microaggregates were stabilized within earthwormformed large soil macroaggregates $(>2000 \mu \mathrm{m})$ in treatments with earthworms, than in treatments without earthworms. Our findings indicate that earthworms are likely to consume existing soil structures of different sizes and can rapidly rearrange them to produce new soil macroaggregates, which could be more pronounced in long-term conservation tillage soils.

\section{$4.2{ }^{13} \mathrm{C}$ and rhizodeposit carbon in the soil aggregates}

Our most striking results may have come from the comparison of the $\delta^{13} \mathrm{C}$ signatures and the fate of rhizodeposit carbon between soil aggregates, with and without earthworms, under different soil tillage treatments. In the presence of earthworms, more $\delta^{13} \mathrm{C}$ signatures and rhizodeposit carbon were incorporated into the soil macroaggregates ( $>2000 \mu \mathrm{m}$ and $250-2000$ $\mu \mathrm{m})$ than in the treatments without earthworms, and the effects were more obvious in the NT soils (Fig. 3). Yavitt et al. (2015) found that earthworms greatly increased the proportion of root-derived carbon incorporated into soil macroaggregates and then accelerated the process of root carbon incorporation into soil aggregates. Furthermore, earthworms can directly absorb carbon recently fixed by plants (Huang et al., 2015) or the newly fixed fraction contained in soil aggregates (Fonte et al., 2012). Arai et al. (2013) found that earthworm activity and plants rapidly increased soil carbon content by incorporating fresh carbon into the soil macroaggregtes in a no-tillage system. Our previous investigation showed that earthworms increased maize biomass, and the $\delta^{13} \mathrm{C}$ signatures in the maize roots reflected the input of ${ }^{13} \mathrm{C}$-labeled photosynthetic carbon into the soil. In the NT soils, with the higher maize biomass and the activity of soil microbes, earthworms could allocate relatively more ${ }^{13} \mathrm{C}$ to the soil (Zhu et al., 2019). Therefore, due to earthworm activities, such as mixing the soil and feeding, the increased ${ }^{13} \mathrm{C}$ values in the treatments with earthworms were largely due to the addition of new photo- 
synthetic carbon. These findings indicate that earthworms promote the incorporation of fresh organic matter into soil macroaggregates. Moreover, the findings indicate that plant roots and earthworms are closely related in the formation of soil aggregates, and the proper management of soils by these two organisms should be considered simultaneously.

Earthworms regulate carbon dynamics mainly through their gut processes to protect the carbon from the effects of their digested aggregates. Annually, earthworms generate from a few hundred to thousands of milligrams of casts (dry weight) per ha (Lavelle et al., 1992). Once these casts dry, they become compact and can be kept intact for several years without being destroyed by physical processes or ingested by other invertebrate ecosystem engineers (Blanchart et al., 1999). This process can promote carbon stabilization in the soil aggregates that are formed in earthworm casts (Bossuyt et al., 2005; Pulleman et al., 2005). Therefore, if earthworms regulate or protect rhizodeposit carbon, more rhizodeposit carbon would be observed in their gut contents than in the control soils (Huang et al., 2015). Our previous research results showed that the amounts of rhizodeposit carbon in earthworm guts were significantly higher than those in the control soils (Zhu et al., 2019). Furthermore, compared with the CT soils, NT soils had higher rhizodeposit carbon in the earthworm guts. Additionally, in this area, the 14-year (20022016) NT system could have enhanced the structure and function of the soil food web via bottom-up effects (Zhang et al., 2015), forming a stable soil ecosystem (Kong and Six, 2010; Zhang et al., 2013). Gong et al. (2019) reported that the assemblage of soil microbial communities changed drastically between soil aggregate fractions and with the presence of the earthworms. Additionally, the microbial communities in bulk soil were more similar to those in large macroaggregates $(>2$ $\mathrm{mm}$ ) or small aggregates $(<0.053 \mathrm{~mm}$ ) (Wieland et al., 2001; Gong et al., 2019). These observations indicate that the effects of earthworms on rhizodeposit carbon transformation depend on the earthworms on rhizosphere microbiota (Huang et al., 2015), whereas the absence of earthworm, by the effects the activities of soil microbes, could limit the transformation of rhizodeposit carbon. Another investigation indicated that the amount of root-derived $\mathrm{CO}_{2}$ was significantly higher under the CT system than under the NT system (Mo et al., 2019). Therefore, in NT soils, earthworms could have allocated relatively large amounts of fixed ${ }^{13} \mathrm{C}$ belowground and the earthworms are more likely to transfer the root-derived carbon and protect it in the soil macroaggregates.

Furthermore, earthworms increase plant productivity (van Groenigen et al., 2014) and the proportion of photosynthesized carbon that is incorporated into the soil by earthworm activity (Nieminen et al., 2015; Huang et al., 2015). Roots and associated rhizodeposits are presumably the main sources of fresh organic matter facilitating soil macroaggregate formation (Miller and Jastrow, 1990; Wilson et al., 2009). Root-derived carbon was better than leaf and other litter carbon for macroaggregate incorporation (Sánchez-de León et al.,
2014). Recent evidence has shown that earthworms consume significant amounts of root-derived carbon (i.e., root exudates or other labile carbon) (Gilbert et al., 2014) which is immediately incorporated into the soil macroaggregate fractions of rhizosphere soil (Sánchez-de León et al., 2014). Root feeding by earthworms has been rarely reported, and most earthworms seem to avoid feeding on roots, at least in the early stages of root decomposition. However, Decaëns et al. (1999) observed freshly deposited casts on fine roots, thus indicating that roots often utilize the nutrients in casts. Our results clearly showed interactions regarding soil macroaggregate formation given that the soil macroaggregates that were formed in the presence of 2 different engineers (earthworms and roots) were significantly different from the macroaggregates that were formed in the presence of only one organism (roots). Furthermore, the presence of earthworms or the interactions of earthworms with soils had a significant effect on the soil macroaggregates (Table 2). More rhizodeposit carbon and ${ }^{13} \mathrm{C}$ were present in the soil macroaggregates in the treatments with earthworms than in the treatments without earthworms (Fig. 3). This finding seemed to indicate that rhizodeposition was stimulated by earthworm activities and that the earthworms probably fed on root exudates and rhizodeposits (Zangerlé et al., 2011). Another explanation could be that the soil macroaggregates formed by the earthworms were further colonized by roots, and the roots added their rhizodeposits to the soil in specific organic compounds that were then mixed by the earthworms. These results indicate that roots and earthworms do not produce soil macroaggregates in isolation; instead, their additive effects impact the mixed source structure. Our findings also indicated that there was an important interaction between the earthworms and roots in soils under different tillage regimes, that not only helped improve the stability of aggregates, but also helped stabilize the organic residues in the soil aggregates.

\section{Conclusions}

The presence of earthworms stimulated the immobilization of rhizodeposit carbon, and the earthworms in the NT soils promoted more rhizodeposit carbon retention in soil macroaggregates than those in the CT soils. Our results showed that earthworms have a significant effect on soil aggregation that increased the abundance of soil macroaggregates and negatively impacted the formation of soil microaggregates. The interaction between rhizodeposits and earthworms could have a major effect on soil function regulation during plant growth, such as soil aggregation, soil organic matter priming, and different functional groups of earthworms. Furthermore, earthworms could affect rhizosphere soil microbes, leading to an increase in the retention of rhizodeposit carbon in the soil macroaggregates, which is more obvious in the long-term notill soil. These interactions require further research. 


\section{Acknowledgments}

This study was supported by the National Natural Science Foundation of China $(41430857 ; 41501263)$, the Foundation for University Young Key Teacher of Henan Province (2017GGJS141), Science and Technology Project of Henan Province (172102410054), the Program of Introducing Talents of Discipline to Universities (No.B16011), National Science \& Technology Fundamental Resources Investigation Program of China (2018FY100300) and sponsored by Program for Science \& Technology Innovation Talents in Universities of Henan Province (21HASTIT015). The authors also wish to thank the editors and anonymous reviewers for their useful comments and suggestions on this manuscript.

\section{References}

Angers, D.A., Caron, J., 1998. Plant-induced changes in soil structure: processes and feedbacks. Biogeochemistry 42, 55-72.

Arai, M., Tayasu, I., Komatsuzaki, M., Uchida, M., Shibata, Y., Kaneko, N., 2013. Changes in soil aggregate carbon dynamics under notillage with respect to earthworm biomass revealed by radiocarbon analysis. Soil \& Tillage Research 126, 42-49.

Ayuke, F.O., Pulleman, M.M., Vanlauwe, B., de Goede, R.G.M., Six, J., Csuzdi, C., Brussaard, L., 2011. Agricultural management affects earthworm and termite diversity across humid to semi-arid tropical zones. Agriculture, Ecosystems \& Environment 140, 148 154.

Bai, Z., Caspari, T., Ruiperez Gonzalez, M., Batjes, N.H., Mäder, P., Bünemann, E.K., de Goede, R., Brussaard, L., Xu, M., Santos Ferreira, C.S., Reintam, E., Fang, H., Mihelič, R., Glavan, M., Tóth, Z., 2018. Effects of agricultural management practices on soil quality: a review of long-term experiments for Europe and China. Agriculture, Ecosystems \& Environment 265, 1-7.

Blanchart, E., Albrecht, A., Alegre, J., Duboisset, A., Pashanasi, B., Lavelle, P., Brussaard, L., 1999. Effects of earthworms on soil structure and physical properties. In: Lavelle, P., Brussaard, L., Hendrix, P., eds. Earthworm Management in Tropical Agroecosystems. CAB International, Wallingford, pp. 139-162.

Boag, B., Legg, R.K., Neilson, R., Palmer, L.E., Hackett, C.A., 1994. The use of Taylor's power law to describe the aggregated distribution of earthworms in permanent pasture and arable soil in Scotland. Pedobiologia 38, 303-306.

Boone, R.D., Nadelhoffer, K.J., Canary, J.D., Kaye, J.P., 1998. Roots exert a strong influence on the temperature sensitivity of soil respiration. Nature 396, 570-572.

Bossuyt, H., Six, J., Hendrix, P.F., 2005. Protection of soil carbon by microaggregates within earthworm casts. Soil Biology \& Biochemistry $37,251-258$.

Briones, M.J., Schmidt, O., 2017. Conventional tillage decreases the abundance and biomass of earthworms and alters their community structure in a global meta-analysis. Global Change Biology 23, 4396-4419.

Brown, G.G., Edwards, C.A., Brussaard, L., 2004. How earthworms affect plant growth: burrowing into the mechanisms. In: Edwards, C.A., ed. Earthworm Ecology. CRC, Boca Raton, pp. 13-49.
Capowiez, Y., Cadoux, S., Bouchant, P., Ruy, S., Roger-Estrade, J., Richard, G., Boizard, H., 2009. The effect of tillage type and cropping system on earthworm communities, macroporosity and water infiltration. Soil \& Tillage Research 105, 209-216.

Cheng, L., Booker, F.L., Tu, C., Burkey, K.O., Zhou, L.S., Rufty, T.W., Fiscus, E.L., Shew, D.H., Hu, S., 2012. Arbuscular mycorrhizal fungi increase organic $\mathrm{C}$ decomposition under elevated $\mathrm{CO}_{2}$. Science 337, 1084-1088.

Decaëns, T., Jiménez, J.J., Lavelle, P., 1999. Effect of exclusion of the anecic earthworm Martiodrilus carimaguensis and Morena on soil properties and plant growth in grasslands of the eastern plains of Colombia. Pedobiologia 43, 835-841.

Denef, K., Six, J., 2006. Contributions of incorporated residue and living roots to aggregate-associated and microbial carbon in two soils with different clay mineralogy. European Journal of Soil Science 57, 774-786.

Elliott, E.T., 1986. Aggregate structure and carbon, nitrogen, and phosphorus in native and cultivated soils. Soil Science Society of America Journal 50, 627-633.

Fahey, T.J., Yavitt, J.B., Sherman, R.E., Groffman, P.M., Fish, M.C., Maerz, J.C., 2011. Transport of carbon and nitrogen between litter and soil organic matter in a Northern Hardwood forest. Ecosystems (New York, N.Y.) 14, 326-340.

Fonte, S.J., Quintero, D.C., Velásquez, E., Lavelle, P., 2012. Interactive effects of plants and earthworms on the physical stabilization of soil organic matter in aggregates. Plant and Soil 359, 205-214.

Gilbert, K.J., Fahey, T.J., Maerz, J.C., Sherman, R.E., Bohlen, P., Dombroskie, J.J., Groffman, P.M., Yavitt, J.B., 2014. Exploring carbon flow through the root channel in a temperate forest soil food web. Soil Biology \& Biochemistry 76, 45-52.

Gong, X., Wang, S., Wang, Z.W., Jiang, Y.J., Hu, Z.K., Zheng, Y., Chen, X.Y., Li, H.X., Hu, F., Liu, M.Q., Scheu, S., 2019. Earthworms modify soil bacterial and fungal communities through enhancing aggregation and buffering $\mathrm{pH}$. Geoderma 347, 59-69.

Groffman, P.M., Fahey, T.J., Fisk, M.C., Yavitt, J.B., Sherman, R.E., Bohlen, P.J., Maerz, J.C., 2015. Earthworms increase soil microbial biomass carrying capacity and nitrogen retention in northern hardwood forests. Soil Biology \& Biochemistry 87, 51-58.

Guggenberger, G., Thomas, R.J., Zech, W., 1996. Soil organic matter within earthworm casts of an anecic-endogeic tropical pasture community, Colombia. Applied Soil Ecology 3, 263-274.

Huang, J.H., Zhang, W.X., Liu, M.Y., Briones, M.J.I., Eisenhauer, N., Shao, Y.H., Cai, X.A., Fu, S.L., Xia, H.P., 2015. Different impacts of native and exotic earthworms on rhizodeposit-carbon sequestration in a subtropical soil. Soil Biology \& Biochemistry 90, 152-160.

Jones, D.L., Nguyen, C., Finlay, R.D., 2009. Carbon flow in the rhizosphere: carbon trading at the soil-root interface. Plant and Soil 321, 5-33.

Jouquet, P., Bottinelli, N., Podwojewski, P., Hallaire, V., Duc, T.T., 2008. Chemical and physical properties of earthworm casts as compared to bulk soil under a range of different land-use systems in Vietnam. Geoderma 146, 231-238.

Judas, M., 1992. Gut content analysis of earthworms (Lumbricidae) in a beechwood. Soil Biology \& Biochemistry 24, 1413-1417.

Kaštovská, E., Šsantrůčková, H., 2007. Fate and dynamics of recently 
fixed $C$ in pasture plant-soil system under field conditions. Plant and Soil 300, 61-69.

Kong, A.Y.Y., Six, J., 2010. Tracing root vs. residue carbon into soils from conventional and alternative cropping systems. Soil Science Society of America Journal 74, 1201-1210.

Lavelle, P., Blanchart, E., Martin, A., Spain, A.V., Martin, S., 1992. Impact of soil fauna on the properties of soils in the humid tropics. Myths and Science of Soils of the Tropics. Soil Science Society of America and American Society of Agronomy, Special Publication no. 29, Madison, 157-185.

Liang, A.Z., Zhang, X.P., Fang, H.J., Yang, X.M., Drury, C.F., 2007. Short-term effects of tillage practices on organic carbon in clay loam soil of northeast China. Pedosphere 17, 619-623.

Lubbers, I.M., Pulleman, M.M., Groenigen, J.W.V., 2017. Can earthworms simultaneously enhance decomposition and stabilization of plant residue carbon? Soil Biology \& Biochemistry 105, 12-24.

Miller, R.M., Jastrow, J.D., 1990. Hierarchy of root and mycorrhizal fungal interactions with soil aggregation. Soil Biology \& Biochemistry $22,579-584$.

Mo, F., Zhang, Y.Y., Li, T., Wang, Z.T., Yu, K.L., Wen, X.X., Xiong, Y.C., Jia, Z.K., Liao, Y.C., 2019. Fate of photosynthesized carbon as regulated by long-term tillage management in a dryland wheat cropping system. Soil Biology \& Biochemistry 138, 107581.

Nieminen, M., Hurme, T., Mikola, J., Regina, K., Nuutinen, V., 2015. Impact of earthworm Lumbricus terrestris living sites on the greenhouse gas balance of no-till arable soil. Biogeosciences 12 , 5481-5493.

Pinheiro, E.F.M., Pereira, M.G., Anjos, L.H.C., 2004. Aggregate distribution and soil organic matter under different tillage systems for vegetable crops in a Red Latosol from Brazil. Soil \& Tillage Research 77, 79-84.

Pulleman, M.M., Six, J., Van Breemen, N., Jongmans, A.G., 2005. Soil organic matter distribution and microaggregate characteristics as affected by agricultural management and earthworm activity. European Journal of Soil Science 56, 453-467.

Rillig, M.C., 2004. Arbuscular mycorrhizae, glomalin, and soil aggregation. Canadian Journal of Soil Science 84, 355-363.

Rogers, H.H., Runion, G.B., Krupa, S.V., 1994. Plant responses to atmospheric $\mathrm{CO}_{2}$ enrichment with emphasis on roots and the rhizosphere. Environmental Pollution 83, 155-189.

Sánchez-de León, Y., Lugo-Pérez, J., Wise, D.H., Jastrow, J.D., González-Meler, M.A., 2014. Aggregate formation and carbon sequestration by earthworms in soil from a temperate forest exposed to elevated atmospheric $\mathrm{CO}_{2}$ : A microcosm experiment. Soil Biology \& Biochemistry 68, 223-230.

Six, J., Bossuyt, H., Degryze, S., Denef, K., 2004. A history of research on the link between (micro) aggregates, soil biota, and soil organic matter dynamics. Soil \& Tillage Research 79, 7-31.

Six, J., Elliott, E.T., Paustian, K., 2000. Soil macroaggregate turnover and microaggregate formation: a mechanism for $C$ sequestration under no-tillage agriculture. Soil Biology \& Biochemistry 32, 2099 2103.

Six, J., Feller, C., Denef, K., Ogle, M., Moraes, J.C., Albrecht, A., 2002. Soil organic matter, biota and aggregation in temperate and tropical soils: effects of tillage. Agronomie 22, 755-775.

Six, J., Paustian, K., 2014. Aggregate-associated soil organic matter as an ecosystem property and a measurement tool. Soil Biology \& Biochemistry 68, A4-A9.

SDA, 1993. Soil Survey Manual. United States Department of Agriculture Handbook No. 18. US Department of Agriculture, Washington, DC.

van Groenigen, J.W., Lubbers, I.M., Vos, H.M.J., Brown, G.G., De Deyn, G.B., van Groenigen, K.J., 2014. Earthworms increase plant production: a meta-analysis. Scientific Reports 4, 63-65.

Wander, M.M., Yang, X., 2000. Influence of tillage on the dynamics of loose and occluded-particulate and humified organic matter fractions. Soil Biology \& Biochemistry 32, 1151-1160.

Wieland, G., Neumann, R., Backhaus, H., 2001. Variation of microbial communities in soil, rhizosphere, and rhizoplane in response to crop species, soil type, and crop development. Applied and Environmental Microbiology 67, 5849-5854.

Wilson, G.W.T., Rice, C.W., Rillig, M.C., Springer, A., Hartnett, D.C., 2009. Soil aggregation and carbon sequestration are tightly correlated with the abundance of arbuscular mycorrhizal fungi: results from long-term field experiments. Ecology Letters 12, 452461.

Yavitt, J.B., Fahey, T.J., Sherman, R.E., Groffman, P.M., 2015. Lumbricid earthworm effects on incorporation of root and leaf litter into aggregates in a forest soil, New York State. Biogeochemistry 125, 261-273.

Zangerlé, A., Pando, A., Lavelle, P., 2011. Do earthworms and roots cooperate to build soil macroaggregates? A microcosm experiment. Geoderma 167-168, 303-309.

Zhang, C., Liu, G.B., Xue, S., Song, Z.L., Zhang, C.S., 2011. Fractal features of rhizosphere soil microaggregate and particle - size distribution under different vegetation types in the Hilly-Gully region of Loess Plateau. Scientia Agricultura Sinica 44, 507515.

Zhang, S., Li, Q., Lü, Y., Sun, X., Jia, S., Zhang, X., Liang, W., 2015. Conservation tillage positively influences the microflora and microfauna in the black soil of Northeast China. Soil \& Tillage Research 149, 46-52.

Zhang, W.X., Hendrix, P.F., Dame, L.E., Burke, R.A., Wu, J.P., Neher, D.A., Li, J.X., Shao, Y.H., Fu, S.L., 2013. Earthworms facilitate carbon sequestration through unequal amplification of carbon stabilization compared with mineralization. Nature Communications 4, 2576.

Zhang, Y., Li, X.J., Gregorich, E.G., McLaughlin, N.B., Zhang, X.P., Guo, Y.F.,Liang, A.Z., Fan, R.Q.,Sun, B.J.,2018. No-tillage with continuous maize cropping enhances soil aggregation and organic carbon storage in Northeast China. Geoderma 330, 204-211.

Zhu, B., Gutknecht, J.L.M., Herman, D.J., Keck, D.C., Firestone, M.K., Cheng, W., 2014. Rhizosphere priming effects on soil carbon and nitrogen mineralization. Soil Biology \& Biochemistry 76, 183-192.

Zhu, X.Y., Chang, L., Liu, J., Zhou, M.H., Li, J.J., Gao, B., Wu, D.H., 2016. Exploring the relationships between soil fauna, different tillage regimes and $\mathrm{CO}_{2}$ and $\mathrm{N}_{2} \mathrm{O}$ emissions from black soil in China. Soil Biology \& Biochemistry 103, 106-116.

Zhu, X.Y., Hu, Y.C., Wang, W., Wu, D.H., 2019. Earthworms promote the accumulation of maize root-derived carbon in a black soil of Northeast China, especially in soil from long-term no-till. Geoderma 340, 124-132. 